\title{
Архітектоніка копірайтингового тексту
}

\author{
Підмогильна Н.В., Левщанова О.0.
}

\section{Дніпровський начіональний університет імені Олеся Гончара}

\begin{abstract}
Український ринок копірайтингу наразі перебуває на етапі остаточного становлення та активного розвитку, і на ньому відчувається велика потреба саме в україномовних копірайтингових текстах, оскільки на державному рівні ухвалено низку документів, у яких зазначено, що будь-який інтернет-ресурс у межах України повинен функціонувати українською або мати повноцінну україномовну версію. Законодавча підтримка суттєво розширила межі українського копірайтингу та сформувала попит на кваліфікованих професіоналів у сфері текстотворення. Сьогодні світові тенденції та інновації в царині копірайтингу поширюються в українському медіапросторі безпосередньо - без посередництва чи запозичення зі сфери російського копірайтингу.

Пропонуємо визначати «копірайтинг» як вид професійної діяльності, спрямований на створення оригінальних текстів інформаційного, іміджевого, рекламного характеру в текстовому, аудіо- та відеоформаті. Копірайтинговий текст - оригінальний текст, створений професійним копірайтером, що має рекламні, інформаційні, презентаційні, іміджеві та маркетингові функції й виконує функцію просування творів/послуг/компаній/осіб, спрямований на певну цільову аудиторію.

Мережа Інтернет - середовище, що сприяє виникненню комунікації чи певної взаємодії між замовниками та виконувачами, щодня зростає кількість спеціалізованих/тематичних/інформаційних ресурсів, які мають бути наповнені відповідним контентом. Для створення та ефективного функціонування будь-якої платформи необхідні знання щодо видів копірайтингових текстів, їх призначення, функцій, особливостей побудови та подальшої оптимізації задля якісного просування в мережі.
\end{abstract}

Ключові слова: копірайтинг; копірайтинговий текст; копірайтер; рерайтинг; фрилансове середовище; заголовок; лід.

\section{1. Вступ}

Постановка проблеми. Актуальність дослідження питань, пов'язаних із копірайтингом як досить новим явищем в українському медіапросторі, зумовлена розвитком копірайтингу як відносно самостійного напрямку рекламної діяльності та затвердженням на законодавчому рівні української мови як обов'язкової для функціонування всіх інтернет-ресурсів на теренах України. Важливим аспектом зазначеної проблеми $\epsilon$ власне створення та редагування копірайтингових текстів, оскільки вони за змістом, структурою, призна-

Pidmohylna N., Doctor of Philological Sciences, Professor, Head of the Department of Publishing and Intercultural Communication, e-mail address: podmogilnaya_n@fszmk.dnu.edu.ua, ORCID: https://orcid.org/0000-0002-4044-981X,

Levshchanova O., Graduate Student, e-mail address: levschanova@icloud.com, Oles Honchar Dnipro National University, 13, Naykova str., Dnipro, 49050, Ukraine ченням та функціями відрізняються від інших видів текстів. Сучасність здійсненого нами дослідження зумовлена недостатнім вивченням копірайтингового та фрилансового середовища в Україні загалом. Дослідження копірайтингу та копірайтингових текстів у різних аспектах дає можливість визначити основні засади та принципи роботи копірайтерів, сучасний стан копірайтингу в Україні, а також передбачає ґрунтовний розгляд цієї галузі та розробку власних технік, технологій, продуктів, що підвищуватимуть якість роботи українських копірайтерів. Огляд роботи фрилансових бірж текстів, копірайтингу та рерайтингу дає можливість

Підмогильна Н.В., докторка філологічних наук, професорка, завідувачка кафедри видавничої справи та міжкультурної комунікації, електронна адреса: podmogilnaya_n@fszmk.dnu.edu.ua, ORCID: https://orcid.org/0000-0002-4044-981X,

Левщанова 0.0., магістр, електронна aдреса: levschanova@icloud.com, Дніпровський національний університет імені О.Гончара, вул. Наукова, 13, Дніпро, 49050, Україна 
зрозуміти, у який спосіб функціонує цей напрямок у мережі Інтернет, зокрема, у нашій країні та закордоном, які перспективи розвитку має український копірайтер.

Аналіз останніх досліджень та публікацій. Говорячи про копірайтинг, передусім необхідно звернутися до поширених дефініцій термінів копірайтинг та копірайтерський/копірайтинговий текст, поданих різними дослідниками, зокрема: М. Айзенбергом, Н. Блиновою та О. Кириловою, К. Болдіною, Ю. Земською та Є. Кузнецовою, Е. Роббінс. Проте слід зазначити, що до формулювання наукового визначення «копірайтингу» та «копірайтера» як людини, яка займається копірайтингом, автори та дослідники вдаються досить рідко, - частіше знаходимо опис функцій та завдань копірайтера, мету копірайтингового тексту або нечітке визначення цього артефакту, пов'язане з об'єктом, що продається. Е. Роббінс (Робін Бредлі) - письменниця, підприємець, авторка семінару "10 ефективних кроків до ефективного копірайтингу", а також бізнес-тренер пояснює термін так: «Копірайтинг - це написання текстів, які продають товар, послугу чи персону» (Robbins, 2004). Вона підкреслює, що головне для копірайтера - спонукати текстом до купівлі, а не зосереджуватись на креативності. М. Айзенберг пропонує таку дефініцію: процес написання оригінальних текстів, які просувають думку, ідею, бізнес чи особу. Зазвичай тексти поширюються в друкованому, відео- та аудіоформатах. Головна мета таких текстів - переконати реципієнта зробити необхідну дію (Ajzenberg, 1993). Ю. Бернадська (2003) та К. Іванова (2010) у своїх посібниках із копірайтингу не подають окремих визначень, а ототожнюють копірайтингові тексти з рекламними, а сам копірайтинг - з рекламною діяльністю, PR-комунікацією.

Отже, автори посібників не виокремлюють копірайтинг у самостійний напрямок у сфері комунікації, а пояснюють його як процес творення текстів певного жанру. Ю. Земська та Є. Кузнецова (2014) зазначають, що копірайтинг - це процес складання текстів інтегрованих маркетингових комунікацій, спрямованих на просування ідеї, товару, людини. О. Назайкін (2007) у своєму посібнику підкреслює, що копірайтер - це окрема посада, на якій спеціаліст повинен створювати ефективні рекламні тексти, а також оформлювати комерційні пропозиції. Дослідники акцентують увагу на тому, що до копірайтингових текстів можна віднести рекламні тексти, тексти для просування в соціальних мережах, а також інші, що мають певну пропозицію щодо купівлі товару. Це свідчить про розширення сфери копірайтингу, зокрема, про те, що це поняття вбирає процеси створення різних текстів, орієнтованих на певну цільову аудиторію. На думку К. Болдіної, визначення терміну повинно свідчити про відокремлення копірайтингу від конкретної рекламної практики. Таким чином, К. Болдіна формулює одну з головних тез визначення копірайтингу: копірайтинговий текст - це текст, підготовлений профе- сійним копірайтером (Boldina, 2016, с. 165). Дослідниця пропонує таке визначення: «копірайтинговий текст -текст інформаційного, рекламного або іміджевого характеру, написаний професійним копірайтером $з$ метою досягнення конкретних маркетингових завдань, зокрема, просування продукту/послуги/ фірми у мережі Інтернет (Boldina, 2016, с. 166). Ця думка підтверджена класифікацією копірайтингових текстів:

- рекламні тексти (просування);

- тексти, що продають (комерція);

- іміджеві тексти (позиціонування);

- презентаційні тексти (анонсування);

- тексти, що інформують (інформування та пресматеріали);

- веборієнтовані тексти (наповнення контентом);

- SEO-тексти (тексти, оптимізовані під пошукові системи);

- SMM-тексти (тексти для соціальних мереж) (Boldina, 2016, c. 166-167).

Очевидно, що копірайтинг уже вийшов за межі лише рекламних текстів, оскільки набуває, наприклад, функцій інформування, підвищення індексування контенту (Boldina, 2016, с. 166).

О. Кривоносов подає таке визначення копірайтингу у сфері PR: копірайтинг - технологія створення текстів у сфері паблік рилейшнз, а також професійна діяльність зі створення текстів публічних комунікацій (Krivonosov, 2015, с. 153). Акцентуючи відмінності рекламного тексту від копірайтерського, науковець подає таке визначення останнього: вербальний або вербально-візуальний (креолізований) текст, що поширюється у публічному просторі за допомогою 3МІ, прямої доставки, інтернет-розсилки, корпоративних каналів, ініційований суб'єктом PR або реклами, що містить рекламну або PR-інформацію, спрямований певній групі цільової громадськості або цільової аудиторії, що слугує реалізації товару/послуги або формуванню іміджу товару/послуги, корпорації, публічної персони, з прихованим (рідше уявним) авторством (Krivonosov, 2015, с. 155).

Проаналізувавши й узагальнивши подані дефініції, а також ступінь наукової розробки цієї проблеми, пропонуємо визначати копірайтинг як вид професійної діяльності, спрямований на створення оригінальних текстів інформаційного, іміджевого, рекламного характеру в текстовому, аудіо- та відеоформаті, а копірайтинговий текст - це оригінальний текст, створений професійним копірайтером, що має рекламні, інформаційні, презентаційні, іміджеві та маркетингові функції й виконує функцію просування творів/послуг/компаній/ осіб і спрямований на певну цільову аудиторію.

Мета статті полягає в тому, щоб визначити найважливіші складові копірайтингового тексту, особливості його побудови та критерії якості з урахуванням функціонування українського ринку копірайтингу.

06'єкт дослідження - копірайтинговий текст як специфічний текстовий формат. 
Методи дослідження. Під час збору інформації застосовано метод систематизації та описовий метод для вивчення різних видів копірайтингових текстів. Використано також методи дедукції та індукції задля виокремлення рис сучасного українського ринку копірайтингу. Методи аналізу та синтезу застосовано під час опрацювання інформації щодо фрилансових та копірайтингових бірж праці.

\section{2. Результати дослідження}

Узагальнення інформації щодо розвитку та еволюції копірайтингу як досить поширеного та багатоаспектного явища, що взаємодіє з іншими напрямками масових комунікацій, виокремлення цієї ланки текстотворення у відносно самостійний сегмент, детальний аналіз різних видів такого роду текстів не лише заповнює певну нішу знань, а розширює уявлення про копірайтинг і сприяє оптимізації таких текстів. Розглянувши функції та завдання копірайтингових текстів (обрано систему функціонування дискурсу з 2016 р. через можливість її комплексного всебічного осмислення), навівши ілюстрації, що відповідають меті пропонованої статті, ми в такий спосіб конкретизуємо й унаочнюємо питання архітектоніки копірайтингових текстів, що посприяє покращенню та розвиткові загального стану зазначеної галузі i, сподіваємось, зацікавить наукову спільноту.

\section{3. Обговорення}

Основним призначенням копірайтингового тексту $€$ інформування споживачів і просування в мережі Інтернет. Найактивніше копірайтинг застосовується у сфері офлайн- та онлайн-контактів під час підготовки рекламних матеріалів, що поширюються за допомогою різноманітних медіа, у тому числі й друкованих.

Дослідники розуміють SEO-копірайтинг як певну техніку створення й редагування текстів для вебсайтів таким чином, щоб, по-перше, користувач міг легко прочитати та зрозуміти текст i, по-друге, щоб при цьому текст містив необхідні для просування в пошукових системах ключові слова в потрібних місцях і в необхідних пропорціях (Evdokimov, 2007, с. 89). Завдання SEOкопірайтингу - підвищення рейтингу сайта за результатами видачі пошукових машин при здійсненні пошуку за цільовими ключовими запитами. До копірайтингових належать традиційно і «мінітексти» - слогани, які створюються за своїми правилами для рекламної, корпоративної та політичної (електоральної) сфер. Слоган - різновид копірайтингового тексту, що слугує цілям формування споживацького ставлення до товару/послуги (рекламний слоган) і виражає непрямий зв'язок з характеристиками товару/послуги, формування корпоративної ідентичності компанії, організації (корпоративний) і відображає корпоративні цінності або основні положення партійної програми, що має регіональну забарвленість і сувору формулу лінгвістичної репрезентації (політичний і електоральний слоган) (Krivonosov, 2015, c. 154).
Копірайтер сьогодні створює також сценарні тексти - як тексти сценаріїв рекламних роликів, так і тексти сценаріїв івентів. Оскільки пошукові системи щодня стають "розумнішими», то SEO-копірайтерам доводиться писати тексти, враховуючи безліч нових чинників. У зв'язку з цим ще однією специфічною особливістю роботи копірайтера й рерайтера стає вставка в новий текст необхідних ключових слів і фраз. Як правило, ці слова безпосередньо стосуються діяльності сайта замовника. Найчастіше в ключових фразах слова можуть не поєднуватися один з одним за відмінками, оскільки повторюють найчастіші запити користувачів у пошукових системах. Нерідко це створює копірайтерам додаткові труднощі, адже текст повинен залишатися логічним і граматично правильним. Однак копірайтери при створенні статей повинні органічно використовувати ключові фрази, щоб вони не впадали в очі відвідувачам сайту, але при цьому відігравали необхідну роль при видачі результатів пошукового запиту. Тексти не повинні бути занадто розлогими (не більше 3 тис. знаків), хоча можливі й винятки. Це залежить від розміру шрифту, яким написаний текст на сайті, але бажано, щоб текст займав «один екран», тобто читався за один раз, без прокручування мишкою сторінки сайта вниз (Kostenko, 2012, с. 76).

Заголовок - один 3 найважливіших елементів тексту, безпосередньо спрямованих на продаж або просування. Вважають, що на прочитання заголовку пересічна людина витрачає приблизно 1,5 секунди, отже, саме стільки часу відведено на те, щоб привернути увагу читача. Час утримання сучасного користувача Інтернету на контенті становить 8 секунд (дані дослідження Microsoft Canada в 2013 р., а в 2000 р. цей показник становив 12 секунд). Швидкість реакції активних користувачів Інтернету і тих, хто користується ним в основному для перевірки пошти, становить у середньому 912,3 і 1 149,7 мілісекунди відповідно. Звідси - звичка читати тільки заголовки статей і коментарі до них, кліповість, уривчастий характер сприйняття тексту, основа якого ключові слова, а також більш активне сприйняття саме візуального контенту (особливо аудиторією користувачів у віці 25-34 років) (Boldina, 2016, с. 181).

Рекомендована довжина заголовку - 7 слів (+/- 2 слова) та не більше 45 символів, бажано, щоб заголовок займав 1 рядок (не більше 32 символів), оскільки однослівні заголовки $€$ незрозумілими, а занадто довгі - перенасиченими, вони розпорошують і відвертають увагу (якщо заголовок займає більше 1 рядка, то він має містити на кожному рядку не більше 22 символів). Проте, коли йдеться про копірайтингові тексти, то класичні правила слід дещо трансформувати, оскільки головна мета копірайтера - зацікавити. Основними функціями заголовків у друкованих та мережевих $3 \mathrm{MI} \epsilon$ інформаційна (слугує для розкриття загальної концепції та авторської думки), номінативна (означення та «запам'ятовування» статті) та рекламна (привернення уваги читача), розділова (графічне виокремлення стат- 
ті), оціночно-експресивна (формування певної оцінки), інтеграційна (створення єдиної зв'язної картини тексту) і композиційна (членування тексту на частини) (Kornilova, 2007).

Отже, заголовок повинен:

- бути конкретним (із заголовку одразу має бути зрозуміло, про що йдеться в статті);

- бути простим і зрозумілим (слід використовувати загальновживану лексику, щоб охопити максимальну аудиторію, а також уникати складних та розлогих конструкцій. Скоротити довгий заголовок можна, наприклад, шляхом перенесення уточнювальної його частини в підзаголовок);

- бути спрямованим на цільову аудиторію (наприклад, у заголовку статті про окуляри для зору слід зазначити, що це саме окуляри для зору, щоб не втратити представників цільової аудиторії та позбавити себе зайвих повідомлень);

- бути локалізованим, якщо це важливо (наприклад, оренда автомобілів у Дніпрі актуальна лише для дніпрян та гостей міста);

- містити слова 3 позитивною конотацією (наприклад, прибуток, новий, інноваційний, провідний тощо);

- бути унікальним (бажано не використовувати цитати або запозичення);

- відповідати форматові ресурсу (слід враховувати специфіку сайту, наприклад, інформаційні заголовки можуть бути більш довгими, а рекламні - більш конкретними та концентрованими).

Зрозуміло, що ці загальні рекомендації необхідно узгоджувати з потребами певної цільової аудиторії, враховуючи тематику статті, ресурсу, специфіку сприйняття інформації різними групами - за віком, статтю, можливо, професією чи сферою інтересів.

Зазвичай у заголовку необхідно вписувати ключ: якщо замовником не визначено, який саме ключ треба вписати, потрібно вибрати простий тематичний ключ, який зробить заголовок конкретним, але не перенасиченим. Порівняймо заголовки: «Дешеві навушники Apple у Дніпрі» та «Інноваційні бездротові навушники AirPods» для всеукраїнського інтернетмагазину. По-перше, слово «дешеві» не слід використовувати взагалі, оскільки воно не викликає довіри й не зацікавлює. Реципієнт нерідко інтерпретує слово дешевий як другосортний, неякісний, а значить, такий, що не заслуговує уваги. По-друге, просторова локалізація у формі додавання "у Дніпрі» не завжди є актуальною, враховуючи ту обставину, що інтернет-магазин всеукраїнський. По-третє, у заголовку відсутня конкретика, оскільки не зазначено модель, специфіку та інші характеристики товару, які можуть зацікавити покупців. У другому заголовку $€$ конкретика, зокрема, «бездротові» та назва моделі. Слово інноваційні має позитивну конотацію, і це викликає інтерес.

Наступна складник копірайтингового тексту - лід. Це перший абзац тексту, який повинен містити загальну інформацію про певну проблему/товар/ пропозицію/компанію/особу, яким присвячено текст, або інфопривід, який уведе читача в контекст статті.

Далі розміщено такі структурні частини тексту, які разом складають головну частину та передбачають продаж, у такому порядку:

- оффер (пропозиція) - те, що пропонується клієнтам;

- особливості та переваги пропонованого. Обережно слід працювати з недоліками: в об'єктивному тексті (яким - в ідеалі! - він має бути) не можна замовчувати інформацію про них, але слід подати ї̈ як застереження, деякі особливості роботи (наприклад, у статті про ігровий ноутбук, що має не надто високі показники графіки, слід уточнити, для яких саме програмних продуктів він підходить);

- опис - загальні властивості пропонованого;

- вигода - те, що має переконати читача;

- блок, що містить інформацію щодо можливих запитань та відповідей на них (наприклад, стаття про ігровий ноутбук може викликати питання в користувача щодо можливості оновлення деталей, а у тексті вже буде відповідь на нього), цін, гарантій, способів оплати та доставки;

- заклик до дії.

Якщо текст не спрямований на активні продажі, а має більш інформаційний характер, то після ліду розміщують підзаголовок, а далі - головну частину.

Основна частина тексту займає приблизно 70 \% від загального обсягу статті. Надзвичайно важливо, щоб головну частину було поділено на абзаци і вона містила окремі тематичні підзаголовки. Рекомендації щодо підзаголовків за змістом в основному збігаються з рекомендаціями щодо заголовків. У стислому вигляді відповідні поради зводяться до такого переліку:

- підзаголовок повинен розкривати підтему, про яку йтиметься у наступному фрагменті, оскільки іноді читача цікавить лише окремий аспект, а не стаття загалом;

- підзаголовок слід робити влучним, коротким, лапідарним (не більшим за заголовок), з додаванням тематичного ключа;

- підзаголовок може бути 1 або більше залежно від теми та обсягу статті: 1 заголовок на 600-1000 знаків.

Зауважимо, що кожне речення в основній частині й у тексті загалом має містити закінчену думку, аби в читача після його прочитання не виникало питань, оскільки під час написання статті не завжди можна передбачити, як буде виглядати на екрані зверстаний текст, тому, приміром, якщо речення, що розкривають одну тезу, будуть розірвані, то читач втратить послідовність і логіку думки або взагалі інтерес до матеріалу. Речення не слід робити занадто короткими, а також занадто довгими, оптимальний розмір від 1 до 3 рядків, тобто 40-200 символів.

Кожен абзац повинен розкривати одну мінітему. Бажано, щоб він був не коротше 3-х рядків (не менше 150 символів), а краще від 3-х до 10-ти рядків (до 
800-900 символів). Якщо стаття на екрані виглядатиме суцільним полотном тексту, то таке явище свідчить про непрофесійність працівників порталу, а отже, й низьку якість поданої інформації; а також про індиферентне ставлення до користувачів, оскільки такий матеріал важко сприймати візуально та виокремлювати й фіксувати важливі моменти.

Майже обов'язковими складовими, що упорядковують текст та спрощують сприйняття інформації, $€$ зображення, списки (нумеровані та марковані), таблиці, інфографіка. Доцільно використовувати списки для візуалізації й уніфікації різноманітних переліків. Таблиці виявляються найбільш ефективними під час подання та порівняння характеристик. Графіки та діаграми застосовують не дуже часто - здебільшого у вузькоспеціалізованих тематичних статтях.

Вимоги до зображень, якими копірайтер повинен доповнити власний текст, прості: якість (відповідно до іншого графічного наповнення ресурсу, бажано вище середньої) та формат, відповідність тематиці, відсутність водних або інших знаків, які свідчать про джерело (якщо джерело не зазначено).

У технічному завданні (Т3) до написання статті про смартфони наведено такі рекомендації щодо зображень:

«Вставляем картинки отдельно в папке, называем их так, чтобы можно было легко найти, какая картинка для какой статьи. По тексту оформляем Фото 1 , Фото 2 и др. в тех местах, где должны быть картинки. Название картинки и ее упоминание в тексте должны соответствовать, чтобы легко можно было найти соответствующие. Картинки только с оф. сайтов и рекламные материалы (не берем фото обзорщиков, используем изображения без водяных знаков и желательно без китайских иероглифов). Широкоформатные и в хорошем качестве.

НЕ ВСТАВЛЯЕМ КАРТИНКИ ПОСЛЕ ЗАГОЛОВКОВ И ПОДЗАГОЛОВКОВ».

Бажано, щоб списки, таблиці та інфографіка мали текстову підводку, яка пояснювала б інформацію, що подано далі, - це також частково пов'язано з версткою порталів та розміщенням інформації на сторінці й особливостями відображення на різних девайсах. Наприклад, замовники подають такі вимоги щодо інфографіки у статтях з описом вакансій для порталу працевлаштування:

«В каждой статье должны быть $1-2$ картинки гистограмм статистики по данной вакансии и подведение к инфе, которая есть в статистике. Например, на гистограмме ниже можно увидеть в доступной форме должности, узнать о зарплате в смежных направлениях, возможно, изменить курс поисков».

Заключна частина копірайтингового тексту, як і будь-якого іншого, - висновок. Звісно, висновок має узагальнювати тези та ідеї, подані в статті, але копірайтинговий текст повинен, зокрема, концентрувати увагу читача й спонукати до дії, яку він має здійснити, тобто придбати щось або перейти за посиланням для ознайомлення. Відповідно висновок має містити комбінований ключ, який вказуватиме на дію, «предмет» статті, можливо, локацію. Часто SEOфахівці прописують спеціальні ключові фрази для висновків, оскільки останні речення - та сама фінальна фаза, яка за ідеальних умов має переконати читача остаточно. У висновках доречно повторно згадати головні відмінності та характерні особливості описуваного, а також (якщо пропущено блок щодо гарантій, цін та алгоритму замовлення) позначити способи оплати, доставки, яким чином користувач може замовити товар/послугу чи зв'язатись з менеджером. Отже, висновок $є$ фрагментом, який пов'язує всі ланки: від інфоприводу, опису особливостей до способів оплати та доставки, а також вибудовує зв'язок між різними фірмами та мережами (наприклад, виробник, інтернет-магазин (посередник), кур'єрська компанія, платіжна система, банк), які також можуть вплинути на довіру читача: якщо це відомі компанії, то вірогідність успішної угоди вища, та навпаки.

Приклад структури тексту за ТЗ до написання тексту-опису товару:

«Описание + сноска (тип, страна, выдержка, крепость, цвет, аромат, вкус, послевкусие, объем, тип коробки).

1. В первом абзаце охарактеризуйте виски. Обязательно употребить ключ в первом предложении.

2. Далее сделайте абзац об аромате и вкусовых качествах, расскажите о технологии изготовления.

3. Не должно быть в продающей части «В Евростор вы можете купить», «Купите в нашем магазине». В конце можете рассказать о наградах напитка, а также о том, с чем его пить и сочетать».

Подані нами особливості складових копірайтингових текстів базуються на особливостях сприйняття текстів в інтерактивному середовищі. По-перше, на сприйняття інтернет-тексту впливають параметри екрану та вид девайсу. Деякі портали оптимізують тексти під потреби різних гаджетів: ноутбуків, смартфонів, планшетів, що спрощує сприйняття інформації. Подруге, відсутні просторові межі тексту. Також важливе шрифтове та кольорове оформлення, так само як у друкованих виданнях, але перевага електронних джерел у тому, що можна змінювати кегль (наприклад, технологія хінтування допомагає підганяти шрифт під екранні пікселі, що дозволяє зберегти стилістичні особливості шрифтів) та інші параметри й масштабувати сторінки порталу з будь-якого девайсу. По-третє, інтернет-тексти нелінійні, вони насичені гіперпосиланнями, а майже на кожному ресурсі наявні єрор-uр-вікна.

Ключі - обов'язковий елемент копірайтингового тексту.

Існує кілька способів уведення ключів до тексту:

1. Точне входження: ключова фраза вводиться до тексту так, як подано в Т3 (найчастіше замовники 
подають ключі у називному відмінку однини). Наприклад, текст копірайтера.

2. Чисте входження: те ж саме, що й пряме входження, тобто таке введення ключової фрази, при якому між словами ключової фрази немає розділових знаків. Наприклад, потрібно опублікувати текст копірайтера.

3. Пряме входження: не безумовно точне входження, при якому між словами ключової фрази можуть бути розділові знаки. Наприклад, необхідно опублікувати текст, копірайтера при цьому не турбувати. Ключ у прямому входженні, проте не точному. Пряме входження застосовують для великих неприродних ключових запитів, так ключ виглядає більш природно, ніж при точному входженні.

4. Розбавлене входження: до ключової фрази можна додати кілька слів. Наприклад, текст позаштатного копірайтера необхідно опублікувати.

Для однослівних ключів точне, чисте, пряме та розбавлене входження збігаються.

5. Морфологічне входження: одне чи кілька слів частково змінюють (число, рід, відмінок, час та інші граматичні категорії). Більше слів у ключовій фразі більше варіантів морфологічного входження ключів. Наприклад, тексту копірайтера - текстів копіpaŭmepis.

6. Морфологічне розбавлене входження: зміна одного чи кількох слів за різними граматичними категоріями, а також розрідження додатковими словами. Наприклад, надіслано 10 текстів позаштатного копірайтера.

7. Синонімічне входження: одне чи кілька слів ключової фрази можуть бути замінені синонімами, абревіатурами, скороченнями та ін. Синонімічне входження може бути розбавленим. Наприклад, текст копірайтера - текст позаштатного копера, правила техніки безпеки - правила ТБ.

8. Зворотне входження: зміна порядку слів ключової фрази, і воно може бути, зокрема, прямим чи розбавленим, морфологічним. Наприклад, зверніть увагу копірайтера на текст; необхідно найняти копірайтера, текст для сторінки потрібний терміново.

9. Складне входження: одночасне використання кількох способів входження. Наприклад, тексти за ТЗ копером підготовлені вчасно.

Найчастіше замовники вимагають точного або чистого входження ключів, проте головна вимога органічність їх у тексті, вони повинні виглядати природно, не впадати в око, бути логічними та корисними на своєму місці в тексті. Речення з ключовими фразами повинні нести змістове навантаження, а також бути загалом логічними на фоні абзацу/тексту. Ключові фрази, які містять 3 та більше слів, слід передусім вписувати органічно, іноді навіть відступаючи від Т3, оскільки якісний текст створюється для читачів/користувачів, а вже потім - для пошукових систем.
Щодо розміщення ключових фраз у тексті існують такі правила, які замовники додають до Т3:

- заголовок має містити ключ;

- до підзаголовків бажано додавати ключі;

- до першого речення першого абзацу слід додати ключ;

- останній абзац тексту має містити ключ;

- не слід розміщувати ключі в реченнях, розташованих поспіль (рекомендовано вписувати ключі на відстані 300-500 символів).

У ґрунтовно розроблених Т3 фахівці із SEO прописують «місце» ключів: ключі для заголовку, підзаголовків, ключі для певних тем/підтем. Також існують різні види ключів:

- тематичні (каблучка, срібна каблучка, проба каблучки, розмір каблучки);

- ті, що продають (купити каблучку, придбати срібну каблучку, ціна каблучки);

- ті, що вказують на локацію (каблучка в Україні, золоті каблучки в Дніпрі);

- ті, що вказують на компанію/фірму/ресурс (срібні каблучки КЮЗ);

- комбіновані (купити золоту каблучку КЮз у Дніпрі, ціна срібної каблучки кюз).

Приклади техзавдань у формі таблиць з розподілом ключових фраз текстом, вимогами до їх входження подаємо у табл. 1 і 2.

Деякі замовники вимагають, щоб копірайтер власноруч складав теги title та description.

Title (заголовок мережевого ресурсу, який бачимо в результаті пошуку) - тег, що містить заголовок HTML-документа (SEO-словник, 2018). Description (опис сторінки мережевого ресурсу, розміщений нижче title у пошуковій видачі) - метатег, що містить опис HTML-документа (SEO-словник, 2018). Title найважливіший елемент просування ресурсу, оскільки пошуковий робот звертається передусім до нього, тобто релевантність ресурсу залежить від правильності та влучності тайтлу. Обсяг тайтлу зазвичай вказують такий - 50-80 символів.

Description на самому ресурсі не відображений, проте пошуковий робот враховує його для визначення змісту сторінки та їі місця в пошуковій видачі. Приблизний обсяг для коректного відображення у видачі - 170-300 символів. Кожна сторінка ресурсу повинна мати власний дескрипшн, який буде висвітлювати зміст цієї сторінки, можна вписати ключову фразу чи слово, але зробити це слід природно. На жаль, часто замовники не додають до технічного завдання пояснення та рекомендації щодо цих частин, а вказують лише необхідний обсяг, наприклад: «К тексту прописываем тайтл (70-120 символов с пробелами), дискрипшн (до 230 символов с пробелами) и анонс (200250 символов с пробелами). Текст тайтла, дискрипшина и анонса должен начинаться ключевой фразой».

у контексті вивчення особливостей копірайтингових текстів доцільно зробити огляд найпопулярніших бірж копірайтингу, на яких український копірайтер 
ISSN 2617-1813 (print); ISSN 2617-1821 (online). Communications and Communicative Technologies. Вип. 21. 2021.

Таблиця 1

Технічне завдання до написання статті на тему «Молота кава в Києві»

\begin{tabular}{|c|c|c|}
\hline \multirow{2}{*}{\begin{tabular}{|c|} 
Ключи \\
В названии статьи H1
\end{tabular}} & \multicolumn{2}{|c|}{ Кол-во вхождений } \\
\hline & $\begin{array}{c}\text { Прямое } \\
\text { вхождение }\end{array}$ & $\begin{array}{r}\text { Словоформа } \\
\text { (непрямое) }\end{array}$ \\
\hline $\begin{array}{l}\text { Купить молотый кофе в } \\
\text { Киеве с доставкой по } \\
\text { городу }\end{array}$ & 1 & \\
\hline \multicolumn{3}{|l|}{ В тексте: } \\
\hline молотый кофе цена & & 1 \\
\hline молотый кофе crema & 1 & \\
\hline молотый кофе робуста & & 1 \\
\hline кофе молотый купить & & 1 \\
\hline $\begin{array}{l}\text { кофе натуральный мо- } \\
\text { лолотый цена }\end{array}$ & & 1 \\
\hline 100\% арабика молотая & & 1 \\
\hline \multicolumn{3}{|l|}{$\begin{array}{c}\text { В подзаголовке статьи } \\
\text { H2 }\end{array}$} \\
\hline $\begin{array}{l}\text { Молотый натуральный } \\
\text { кофе - любимые купа- } \\
\text { жи в новом формате! }\end{array}$ & 1 & \\
\hline \multicolumn{3}{|l|}{ В тексте: } \\
\hline $\begin{array}{l}\text { Молотый кофе с кис- } \\
\text { линкой }\end{array}$ & & 1 \\
\hline $\begin{array}{l}\text { Молотый кофе с горе- } \\
\text { чью }\end{array}$ & & 1 \\
\hline $\begin{array}{l}\text { Молотый кофе со слад- } \\
\text { ким вкусом }\end{array}$ & & 1 \\
\hline $\begin{array}{l}\text { Кофе молотый с винны- } \\
\text { ми нотками }\end{array}$ & & 1 \\
\hline $\begin{array}{l}\text { Кофе молотый с нотка- } \\
\text { ми какао }\end{array}$ & & 1 \\
\hline $\begin{array}{l}\text { Кофе молотый с кара- } \\
\text { мельными нотками }\end{array}$ & 1 & \\
\hline $\begin{array}{l}\text { Кофе молотый с медо- } \\
\text { выми нотками }\end{array}$ & 1 & \\
\hline $\begin{array}{l}\text { Кофе молотый с нотка- } \\
\text { ми ореха }\end{array}$ & & 1 \\
\hline \multicolumn{3}{|l|}{$\begin{array}{l}\text { Кофе молотый с пряно- } \\
\text { стями }\end{array}$} \\
\hline \multicolumn{3}{|l|}{$\begin{array}{c}\text { Дополнительные } \\
\text { тематические слова: }\end{array}$} \\
\hline \multicolumn{3}{|l|}{ Эфиопия } \\
\hline \multicolumn{3}{|l|}{ растворимый кофе } \\
\hline \multicolumn{3}{|l|}{ Кофеварка } \\
\hline \multicolumn{3}{|l|}{ Турка } \\
\hline \multicolumn{3}{|l|}{ Крепкий } \\
\hline \multicolumn{3}{|l|}{ amore grano } \\
\hline ГEO & & \\
\hline Киев & & 1 \\
\hline Украина & & 1 \\
\hline
\end{tabular}

Таблиця 2

Технічне завдання до написання статті на тему «Продукція компанії Артвіжн»

\begin{tabular}{|c|c|c|}
\hline Заголовки & & Характер \\
\hline \multirow[t]{4}{*}{ Заголовок } & «Продукція компанії Артвіжн» & \multirow{4}{*}{ інформ } \\
\hline & $\begin{array}{l}\text { Короткий опис продукції, яку } \\
\text { пропонує компанія клієнтам }\end{array}$ & \\
\hline & $\begin{array}{l}\text { Максимально корисно для чита- } \\
\text { ча, разом з тим не використо- } \\
\text { вувати складну та наукову лекси- } \\
\text { ку }\end{array}$ & \\
\hline & $\begin{array}{l}\text { Описати, яку фунцію може вико- } \\
\text { нувати така продукція для } \\
\text { клієнта/бізнесу }\end{array}$ & \\
\hline $\begin{array}{l}\text { Підзаголо- } \\
\text { вок }\end{array}$ & $\begin{array}{l}\text { Описати важливість використан- } \\
\text { ня рекламної продукції для } \\
\text { підприємств та бізнесу, які пере- } \\
\text { ваги вона може принести }\end{array}$ & інформ \\
\hline \multirow[t]{6}{*}{$\begin{array}{l}\text { Підзаголо- } \\
\text { вок }\end{array}$} & $\begin{array}{l}\text { Про види продукції Артвіжн } \\
\text { (перерахувати види та короткий } \\
\text { опис в цілому без детального } \\
\text { опису кожного виду) }\end{array}$ & \multirow{6}{*}{ інформ } \\
\hline & $\begin{array}{l}\text { Оформити у вигляді списку: } \\
\text { Друковані банери та плівки }\end{array}$ & \\
\hline & Вивіски. Таблички & \\
\hline & Лайтбокси & \\
\hline & Сувенірна продукція & \\
\hline & Фотошпалери & \\
\hline \multirow[t]{3}{*}{$\begin{array}{l}\text { Підзаголо- } \\
\text { вок }\end{array}$} & $\begin{array}{l}\text { Про переваги вибору продукції } \\
\text { нашої компанії }\end{array}$ & \multirow{3}{*}{ комерційна } \\
\hline & $\begin{array}{l}\text { Наші сильні сторони, переваги } \\
\text { перед конкурентами }\end{array}$ & \\
\hline & \begin{tabular}{|l|}
$\begin{array}{l}\text { Замовлення послуг компанії, } \\
\text { короткий підсумок тексту }\end{array}$ \\
\end{tabular} & \\
\hline \multirow{6}{*}{ Ключі } & Пряме входження & $\begin{array}{l}\text { Словофор- } \\
\text { ма }\end{array}$ \\
\hline & рекламна продукція & $\begin{array}{l}\text { рекламно- } \\
\text { сувенірна } \\
\text { продукція }\end{array}$ \\
\hline & $\begin{array}{l}\text { виготовлення рекламної про- } \\
\text { дукції }\end{array}$ & $\begin{array}{l}\text { реклама } \\
\text { банери } \\
\text { виготовлен- } \\
\text { ня } \\
\end{array}$ \\
\hline & $\begin{array}{l}\text { виготовлення сувенірної про- } \\
\text { дукції }\end{array}$ & $\begin{array}{l}\text { рекламні } \\
\text { вивіски } \\
\text { покажчики } \\
\end{array}$ \\
\hline & види поліграфічної продукції & $\begin{array}{l}\text { рекламний } \\
\text { щит }\end{array}$ \\
\hline & замовити поліграфічну продукцію & $\begin{array}{l}\text { інфор- } \\
\text { маційний } \\
\text { стенд замо- } \\
\text { вити } \\
\end{array}$ \\
\hline
\end{tabular}

може реалізувати себе. Біржа копірайтингу - це ресурс, який вибудовує комунікацію між замовником та виконавцем. Копірайтер може зареєструватися, отримати доступ до бази замовлень, надіслати запит на виконання завдання, розмістити посилання на кращі свої роботи у якості портфоліо, щоб клієнт звернувся до 
нього самостійно, також на багатьох порталах $є$ рейтинг копірайтера (оцінка, кількість виконаних замовлень тощо). Можливості подібних ресурсів для замовників такі: розміщення замовлення, самостійний пошук автора для виконання роботи, також на деяких порталах існує рейтингова система для замовників.

На жаль, саме українських бірж замало (зокрема, UAtxt, Seoware, 2Polyglot, Freelancehunt). Зосередимося передусім на українських, а також оглянемо російські та міжнародні, де український користувач, копірайтер та замовник, можуть розмістити текст чи оголошення та оплатити послуги чи отримати кошти за свою роботу за допомогою електронних гаманців, грошових переказів тощо.

Почнемо з української біржі UAtxt. Запропоновано такі послуги:

- замовити текст. Після реєстрації як замовника на біржі відкриваються такі можливості: замовлення копірайту/рерайту, коректура/редагування готових текстів, переклад;

- придбати текст. На біржі розміщені готові тексти з різних тем у каталозі;

- продати текст. Після реєстрації у якості автора ви можете розмістити свої унікальні тексти для продажу. Слід чітко сформулювати опис тексту та вказати його вартість. У такий спосіб ви можете підвищити власний рейтинг, знайти замовників для тривалої співпраці.

Зручною особливістю ресурсу $є$ індивідуальний рахунок як для авторів, так і для замовників. 3 його допомогою відбувається оплата замовлень, а виводити кошти можна безпосередньо на банківську картку українського банку, як і перераховувати гроші на рахунок. Проте $є$ низка правил для користувачів:

- заборонено поширювати контент, який містить хибні твердження та факти, порушує авторські права, пропагує дискримінацію тощо;

- усі користувачі повинні спілкуватися лише на цій платформі, розміщення та обмін особистими даними заборонено;

- заборонено рекламу та спам.

Також біржа отримує відсотки від вартості замовлення, оскільки вона $є$ посередником між замовником та виконавцем.

У картці замовлення автори вказують кількість символів, ціну за 1000 символів, унікальність, тему статті та категорію, дату розміщення. У полі для опису статті можуть бути вказані інші показники якості тексту.

Наступна - Seoware - перша українська трасова SEO-біржа вічних статей та посилань. Статистика біржі повідомляє нам, що наразі виконано 2332 завдання, придбано 3805 текстів, 3152 посилання, опрацьовано 3470 вебсайтів, 40 активних завдань. Для отримання доступу до функціоналу ресурсів слід зареєструватися, одразу поповнити баланс власного рахунку за допомогою банківської картки.

Послуги, які надає біржа Seoware: копірайтинг, SMM, крауд-маркетинг, SEO-аудит, оптимізація сайта, управління репутацією, контекстна реклама, наповнення сайтів тощо. У кабінеті виконавця відображена інформація щодо бюджету, виконаних та прийнятих до виконання завдань. Для пошуку замовлень можна використовувати фільтри за типом завдання, майданчиком виконання, вартістю. Якщо завдання передбачає кілька етапів, то наступний етап завдання буде доступним лише після виконання попереднього, а на виконання завдань авторам пропонують фіксований строк - 3 дні. Після схвалення замовником завдання гроші автоматично перераховуються на ваш рахунок, а вивести кошти можна на банківську картку. Автоматично змінюються статуси замовлення, що унаочнює етапи виконання завдання.

Біржа 2Polyglot об'єднує копірайтерів (наразі на ресурсі зареєстровано 11872 особи), перекладачів (25 058 осіб) та викладачів (7 827 осіб), вони мають можливість розмістити відповідні сертифікати, портфоліо, фотокартки та супровідні документи. Платформа налічує 29288 профілів замовників. Копірайтери мають можливість розмістити унікальні тексти для продажу в розділі «Магазин», а задля забезпечення захисту прав авторів для замовників доступно лише 30 слів для безкоштовного перегляду, проте навряд чи цього достатньо, щоб зрозуміти, чи задовольняє готовий текст замовника. Розробники порталу створили систему ранжування профілів та замовлень, а сама платформа $є$ безкоштовною для користувачів. Функція «Безпечна угода» дозволяє захиститися від шахраїв.

У розділі “Магазин» вказана фіксована вартість замовлення, мова, категорія, кількість символів та дата публікації. Зручним для замовників $€$ відображення часу останнього візиту автора. На жаль, поля щодо унікальності тексту немає, проте в описі автор може це вказати за власним бажанням.

Freelancehunt позиціонує себе як платформа № 1 в Україні та № 2 в країнах СНД та охоплює замовників та виконавців зі 155 країн світу. Виконавцям надано можливість безкоштовного користування платформою або оформлення PRO-акаунта. За статистикою платформи зареєстровано загалом (без розподілу за категоріями) 78521 замовник, 205621 виконавець, виконано 203127 проектів (активні наразі 1079 проектів). $€$ каталоги робіт, рейтинги фрилансерів з оцінками та їх рівнем. Freelancehunt - це фриланс-платформа, а не біржа копірайтингу, тому спектр послуг, що їх можуть надати виконавці, максимально широкий - від копірайтингу до малюнків на замовлення. Профіль користувача містить багато корисної інформації, яка допоможе замовнику обрати кращого: спеціалізація із врахуванням рейтингу в межах спеціалізації серед користувачів, верифікація, резюме, портфоліо, відгуки, активність, країна та місто, вік, час останнього відвідування, кількість проєктів тощо.

У картці готового замовлення зазначається вартість, кількість переглядів та опис, за бажанням автора можна додати зображення, скриншот виконаної роботи. Назва картки - гіперпосилання на ре- 
сурс розміщення. У картці замовлення надано опис завдання, оплата та платформа, де можливі виконавці роблять «ставки» на виконання проєкту, є опція, де можна поставити питання щодо особливостей роботи. Вся інформація $є$ публічною, зокрема й «ставки» на виконання. Статистика цін, розміщена на порталі, дає можливість зорієнтуватися як початківцю, так і професіоналу. $€$ послуга резервування коштів для безпечних угод, а також "Бізнес Сейф», який передбачає співробітництво за угодою.

Найпопулярнішими серед російських платформ $€$ Text.ru, Advego, етXT, Главред.

Text.ru - біржа копірайтингу й рерайтингу з можливістю замовити переклад та придбати готові статті. Зазначимо, що це дуже зручна платформа, оскільки розроблено сервіс для перевірки унікальності текстів, який $є$ одним з найпопулярніших. Така система є закритою, оскільки знайти замовлення, створити текст та перевірити його можна на одній платформі. Головні правила користування Text.ru такі:

- заборонено публікувати контент, який містить хибні факти, порушує авторські права, пропагує ненависть та насилля;

- заборонено надавати будь-які особисті дані, комунікація між виконавцем та замовником повинна відбуватись у межах платформи.

Також існують окремі правила для замовників та виконавців, які регламентують їх співпрацю та містять інформацію щодо власних рахунків та оплати виконаних проєктів, а також штрафних санкцій. Цікавим $є$ доповнення щодо типових помилок, яких слід уникати, оскільки грамотність - обов'язковий критерій для текстового контенту. У кожному акаунті як замовника, так і виконавця відображені рейтинг та детальна статистика щодо замовлень на біржі та в розділі “Магазин», а також час останнього відвідування, результати перевірки грамотності та мовні навички. PRO-акаунт можна оформити на день, тиждень, місяць, квартал, рік. Його переваги такі: безкоштовна перевірка на платних сервісах (перевірка сайту, документа, API) до 50000 символів на день; перевірка текстів на унікальність без черги; підвищення рейтингу на 30 \% швидше. У картці замовлення вказується строк виконання, обсяг, опис, вартість, вимоги щодо унікальності, ключові слова, цільова аудиторія, мета тексту, тобто вся необхідна інформація, яка дублює/замінює ТЗ.

Наступна закрита платформа - Advego - пропонує найпопулярніший безкоштовний додаток для перевірки унікальності AdvegoPlagiatus, біржу копірайтингу та магазин унікальних статей. За станом на 2016 р. на біржі було зареєстровано 1300000 користувачів, у розділі «Магазин» щоденно продавались близько 40000 матеріалів. У картці готової статті розміщують інформацію щодо вартості, кількості символів, а також категорію, опис, кілька речень зі статті для ознайомлення, частоту вживання ключо- вих слів, результати перевірки сервісами Advego. У картці замовлення: вартість, мова, детально описане завдання (Т3), тема/категорія. Виконавці можуть подати заявку на виконання, а обрати кращого справа замовника. Можна знайти схожі замовлення за цікавою темою чи категорією. У профілі автора, крім часу останнього відвідування, дати реєстрації, відображено ККД автора за певний період часу (наприклад, 90 днів), місце в рейтингу, статті на продаж. Комісія за користування платформою - $10 \%$. Оплата за виконану роботу здійснюється на рахунок користувача з рахунку замовника, кошти можна вивести на електронний гаманець, проте також зі значною комісією, яка залежить від сайту, де зареєстровано гаманець. Інструменти, доступні на платформі в режимі онлайн: перевірка на плагіат, семантичний аналіз, перевірка унікальності, транслітерація, перевірка орфографії, генератор паролів, генератор URL тощо. Цікаво, що деякі платформи проводять конкурси для авторів, зокрема Advego та Text.ru, що дозволяє покращити власні навички та виграти корисні та грошові винагороди.

Біржа ресурсу Главред допомагає знайти авторів, редакторів, коректорів, видавців. Це проста система у вигляді рейтингу авторів. Картка автора містить спеціалізацію (автор, редактор, коректор та ін.), коментар автора, приклади робіт, посилання на портфоліо та на акаунт у Facebook (за бажанням виконавця), а також пошту. Користування порталом та онлайн-додатком для перевірки текстів безкоштовне.

Біржа контенту еTXT пропонує такі послуги: статті на замовлення (копірайтинг, рерайтинг, переклади), магазин контенту (авторські світлини, готові унікальні статті), робота з текстами (коректура, перевірка унікальності). За станом на 2016 р. загальна кількість користувачів платформи складала 950000 осіб, а кількість статей у "магазині» - більше 177 000. Також для завантаження доступний безкоштовний додаток для перевірки унікальності еTXT. У картці готової статті на платформі вказують обсяг, тип статті, дати розміщення та модернізації, вартість. Доступні: попередній перегляд, перегляд частотних та ключових слів, унікальності. Зауважимо, що кваліфікація автора визначається за результатами тестового завдання. Загалом функціонал біржі контенту еTXT схожий з попередніми платформами, а комісія за користування платформою складає $5 \%$.

Отже, біржі копірайтингу - це фрилансові платформи, які об'єднують представників різних професій: копірайтерів, коректорів, редакторів, перекладачів, викладачів у пошуках віддаленої роботи. На нашу думку, найбільш зручними є закриті системи, які дозволяють провести усі процеси, від отримання замовлення, його виконання до отримання оплати, на одній платформі, зокрема, Text.ru, Advego, eTXT. Привабливими для замовників та виконавців $\epsilon$ «безпечні угоди», які захищають від шахраїв, а також рейтингова система та статистика, які дозволяють 
миттєво оцінити професійність автора та надійність замовника. Крім того, варто згадати про тестові завдання під час реєстрації, граматичні тести, які оцінюють реальні навички та знання авторів.

\section{4. Висновок}

Ми розглянули прийоми побудови та основні складові копірайтингових текстів, іманентні для більшості видів подібних текстів. Наведені зауваги та спостереження не стосуються одного з видів - текстів для чатботів, оскільки тексти для чатботів передусім мають викликати відчуття спілкування з реальною людиною, без додавання штучних ключів. 3 прийомів побудови випливають критерії якості текстів, зокрема, унікальність, заспамленість, «тошнотність», "водність», «натуральність». Відповідність цим критеріям можна перевірити за допомогою таких додатків, як AdvegoPlagiatus, eTXT, text.ru, ContentWatch, Главред. Деякі з них функціонують на платформах фрилансових та копірайтингових бірж, алгоритм роботи яких ми описали. Огляд українських бірж праці та популярних російських бірж для фрилансерів та копірайтерів надає можливість поетапно простежити шляхи пошуку замовників, проєктів, виконання завдань, отримання гонорарів та загалом способи реалізації та перспективи копірайтерів у сфері текстотворення за допомогою мережі Інтернет, а значить, здійснена нами розробка буде корисною для копірайтерів-практиків і початківців, що посприяє розвитку українського ринку копірайтингу, на якому відчутна потреба саме в україномовних текстах.

\section{References}

Ajzenberg, M. (1993). Menedzhment reklami [Advertising management]. Inteltekh (in Russian).

Bernadskaya, Yu.S. (2003). Kopirayting: uchebnoe posobie [Copywriting: a tutorial]. Izdatel'stvo Omskogo GTU (in Russian).

Blynova, N., \& Kyrylova, O. (2018). Copywriting as the effective- ness of online content. Communications and communicative technologies, 18, 13-21. https://doi.org/https:// doi.org/10.15421/291802 (in Russian).

Boldina K. A. (2016). Kopirajtingovyj i reklamnyj teksty: k voprosu o tozhdestvennosti ponyatij [Copywriting and advertising texts: on the question of the identity of concepts]. Problemy sovremennoj nauki i obrazovaniya [Problems of modern science and education], 5(47), 164-167 (in Russian).

Evdokimov N. V. (2007). Osnovy kontentnoj optimizatsii [Fundamentals of content optimization]. I.D. Vil'yams (in Russian).

Zemskaya Yu. N., Kuznetsova E. A. (2014). Spichrajting i kopirajting: filologiya na sluzhbe integrirovannyh marketingovyh kommunikatsij [Speechwriting and copywriting: philology at the service of integrated marketing communications]. Filologiya i chelovek [Philology and people], 4, 137-143 (in Russian).

Ivanova K. A. (2010). Kopirajting: sekrety sostavleniya reklamnyh i PR-tekstov [Copywriting: the secrets of compiling advertising and PR-texts]. Piter (in Russian).

Kornilova, K. E. Funktsii zagolovkov sovremennyh zhurnalistskih tekstov [Functions of headings of modern journalistic texts]. URL: https://cyberleninka.ru/article/n/funktsii-zagolovkovsovremennyh-zhurnalistskih-tekstov (in Russian).

Kostenko, E. V. Kopirajting i rerajting v setevyh SMI - novye vidy zhurnalistiki? [Copywriting and rewriting in online media new types of journalism] Izvestiya saratovskogo universiteta. Seriia: filologiya, zhurnalistika [Izvestia of the Saratov University. New series. Series: philology, journalism], 1(14), 110-113 (in Russian).

Krivonosov, A. D. (2015). Kopirajting: k voprosu ob ob`eme ponyatiya [Copywriting: to the question of the volume of the concept]. Yazyk i kultura v epohu globalizatsii: nauch. konf. Publishing house of St. Petersburg State University of Economics, 152-156 (in Russian).

Nazajkin, A. N. (2007). Reklamnyj tekst v sovremennyh SMI: prakticheskoe posobie [Advertising text in modern media: a practical guide]. Ecsmo (in Russian).

Robbins E. T. 10 steps to effective copywriting. URL: http:// www.etrobbins.com/writing-resources.html.

SEO-slovnik. iGroupUkraine. URL: https://igroup.com.ua/seoarticles/title/ (in Ukrainian).

\section{Pidmohylna N.V., Levshchanova O.O. Architectonics of the copywriting text}

Ukrainian copywriting market is currently at the stage of final formation and active development, and there is a great need for Ukrainian-language copywriting texts, as a number of documents were adopted at the state level, stating that any Internet resource in Ukraine must either function in Ukrainian or have a full Ukrainian version. Legislative support significantly expanded the boundaries of Ukrainian copywriting sphere and shaped the demand for qualified professionals in the field of text creation. Today, global trends and innovations in the field of copywriting are spreading in the Ukrainian media space directly, without mediation or borrowings from the field of Russian copywriting.

The authors propose to define "copywriting" as a type of professional activity aimed at the creation of the original information texts, images, advertisement, audio and video formats. Copywriting text is an original text created by a professional copywriter, which performs advertising, information, presentation, image and marketing functions as well as the function of promotion of works / services / companies / individuals and is aimed at a specific target audience.

The Internet is an environment that promotes communication or certain interaction between customers and performers in the context of the fact that the number of specialised / thematic / information resources that need to be filled with relevant content is growing day after day. In order to create and effectively operate any platform, specialists needs to have knowledge of the types of copywriting texts, their purpose, functions, features of construction and further optimisation for quality promotion in the network.

Keywords: copywriting; copywriting text; copywriter; rewriting; freelance environment; headline; lead paragraph. 